\title{
Laboratory use of hepcidin in renal transplant recipients
}

\author{
Lucija Šimetic ${ }^{*} 1,2$, Lada Zibar ${ }^{3,4}$ \\ 'Department of Clinical Laboratory Diagnostics, Osijek University Hospital, Osijek, Croatia \\ 2Department of Medical Chemistry, Biochemistry and Clinical Chemistry, Faculty of Medicine, University of Osijek, Osijek, Croatia \\ ${ }^{3}$ Department for Dialysis, Osijek University Hospital, Osijek, Croatia \\ ${ }^{4}$ Department of Pathophysiology, Faculty of Medicine, University of Osijek, Osijek, Croatia
}

*Corresponding author: lusimetic@gmail.com

\begin{abstract}
Hepcidin is a small peptide with a critical role in cellular iron homeostasis, as it regulates utilization of stored iron and antimicrobial defense in inflammation (bacterial and fungal). Since it was isolated in 2000, and especially in the last decade, numerous studies aimed to evaluate the clinical use of plasma and urine hepcidin as a marker of anemia, especially anemia of chronic disease and post-transplant anemia (PTA). Hepcidin regulation is delicately tuned by two inflammatory pathways activated by interleukin-6 (IL-6) and bone morphogenic proteins (BMPs) and iron regulated pathway sensitive to circulating transferin-iron (TR-Fe) complex. BMP-mediated pathway and TR-Fe sensitive pathway seem to be connected by hemojuveline, a BMP co-factor that interacts with transferine receptor 2 (TRF2) in cases of high TR-Fe circulatory concentration. In addition to these regulatory mechanisms other regulators and signaling pathways are being extensively researched.

Hepcidin has been identified as an important contributor to morbidity and mortality in end stage renal disease (ESRD) but no such association has jet been found in case of PTA. However, there is an association between higher doses of erythropoiesis-stimulating agents (ESA) and mortality in the posttransplant period and the assumption that hepcidin might play a role in ESA resistance in PTA. Thus the review's main goal was to summarize papers published on the association of hepcidin with PTA, give up-to-date information on hepcidin regulation and on potential therapeutics that optimize hepcidin regulation. We also compared the performances of tests for hepcidin determination and reviewed research on immunosuppressants' (IS) effect on hepcidin concentration.
\end{abstract}

Key words: hepcidin; kidney transplantation; post-transplant anemia; iron homeostasis

\section{Introduction}

We reviewed all studies accessed by literature search of PubMed and SCOPUS from January 2000 to January 2015. The terms used as key words for the search were "hepcidin kidney transplantation" and "hepcidin post-transplant anemia". Additional papers were included after revision of reference lists in the found papers. Acquired data covers hepcidin physiology - regulatory pathways of hepcidin synthesis, isoformes of hepcidin and proteins that bind hepcidin in the circulation, as well as the role of kidneys in hepcidin excretion. Changes in hepcidin concentration after renal transplantation (TX) and their clinical significance could be useful to nephrologists and other clinicians involved in the management of renal transplant recipients. On the other hand, specialists in laboratory medicine could benefit from a systematic review of all available methods used for hepcidin determination in plasma and urine and data on their precision and analytical recovery that we collected. We also gave possible reasons for different hepcidin reference values reported using different methods. Researchers in pharmaceutical industry could be interested in mechanisms that were reported to lower hepcidin and possibly lead to the development of therapeutics that target hepcidin regula- 
tion. Finally, nutritionists could benefit from measurement and monitoring of hepcidin in studies assessing nutritional vs. iron substitution therapy where closer iron absorption is necessary. In this article we tried to address the contribution of high hepcidin concentration to post-transplant anemia (PTA), the possible relationship between hepcidin and other markers of iron status and glomerular filtration rate (GFR) after renal TX, the alteration of hepcidin concentration depending on the type of IS used after renal TX, the association between hepcidin and prohepcidin in the circulation; the differences in performances of tests for hepcidin determination and their current standardization.

\section{Physiology of hepcidin}

\section{Biosynthesis and processing of hepcidin}

Hepcidin is a 25 amino acid (aa) peptide that regulates iron release from its stores. Krause et al. isolated hepcidin from human blood ultrafiltrate in the year 2000 and detected it as a cistein rich peptide with molecular mass of $2789.8 \mathrm{Da}$ on matrix assisted laser desorption ionization-time of flight mass spectrometry (MALDI-TOF MS) (1). It is predominantly synthesized in the liver. Low levels of hepcidin expression have also been detected in various human organs, such as heart, brain, gastrointestinal tract, bladder, lungs, glands, skeletal muscle and kidneys (Table 1). Immunohistochemical studies of liver biopsy samples using various region specific antibodies enabled the localization of hepcidin on the basolateral membranes of hepatocytes in periportal zones, with their concentration decreasing from portal triads towards central veins. There, hepcidin cDNA is translated to
TABLE 1. Expression of the hepcidin gene in different tissues (1).

\begin{tabular}{cc}
\hline Tissue & $\begin{array}{c}\text { Expression of } \\
\text { hepcidin gene* }\end{array}$ \\
\hline $\begin{array}{c}\text { Stomach, duodenum, bladder, thyroid } \\
\text { gland, adrenal gland, prostate gland, } \\
\text { salivary gland, trachea, tonsils, lungs } \\
\text { Brain }\end{array}$ & $1-10$-fold \\
Heart & 25 -fold \\
Liver & 105 -fold \\
\hline
\end{tabular}

Gene expression was measured using real-time quantitative polymerase chain reaction (RT-PCR). Hepcidin expression for each tissue was divided by the value of glyceraldehyde3-phosphate dehidrogenase (GAPDH) housekeeping gene and standardized by kidney expression (1-fold expression).

84 aa preprohormone with 24 aa signal peptide at the $\mathrm{N}$ terminal. After cleavage of the signal peptide, a 60 aa prohepcidin is formed, which is a prohormone without biological activity. Prohepcidin is converted to active hepcidin in plasma by convertases in blood or liver capillaries wall cells. It is possible that hepcidin-25 undergoes some N-terminal cleavage that results in the production of two smaller isoforms (hepcidin-20 and -22), or that these isoforms are products of prohepcidin cleavage by convertase. All isoforms of hepcidin are excreted in urine. Peptide sequence of human hepcidin is shown in Figure 1 (2).

\section{Metabolic role of hepcidin}

Like hepcidin-25, hepcidin-22 is an antimicrobial agent (in vitro), but the biological significance of hepcidin-20 is unknown. Active hepcidin has an immune and iron-regulatory role. Immunological-

Prohepcidin

MALSSQIWAACLLLLLLLASLTSGSVFPQQTGQLAELQPQDRAGARASWMPMFQRRRRRDTHFFICIFCCGCCHRSHCGMCCKT

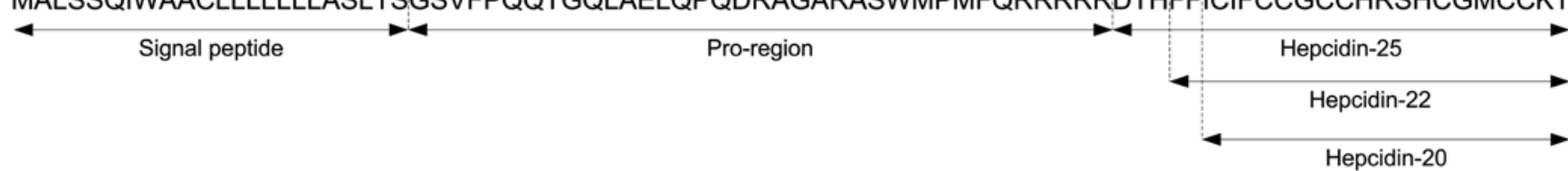

Figure 1. Amino acid sequence of hepcidin precursors and 20-, 22- and 25-hepcidin peptides (2).

Vertical dashed lines denote cleavage sites resulting in different peptide forms. 
ly, hepcidin is consistent with type II acute phase proteins and three inflammatory mediators are needed for its induction in hepatocytes - IL-6, BMP6 and activin B. Immunological activation of hepcidin gene (HAMP - hepcidin antimicrobial peptide) transcription was first discovered in hepatocytes as a reaction to pro-inflammatory IL6 , but similar activation was detected in monocytes. In monocytes incubation with IL-6 and interferon- $\gamma$ (INF $\gamma$ ) increased hepcidin mRNA in a dose-dependent manner, 10-fold higher than in control hepatocyte cultures (HepG2 cells), as well as faster (peak induction of hepcidin mRNA in monocyte was at 1 hour of incubation and in HepG2 cells at 3 - 6 hours) (3). Higher hepcidin plasma concentrations in pro-inflammatory milieu are needed for protective reasons. In bacterial infection hepcidin "hides" iron in its stores from bacteria that have high-affinity iron-binding siderophores for retrieving iron from hosts' transferrin and using it for their optimal growth and metabolism. It also kills bacteria on contact, like other defensin proteins (4). It is possible that in the same way elevated hepcidin makes it harder for cancer cells to get the iron they need for their growth (5).

Hepcidin's iron-regulatory function consists in disabling the passage of stored iron from enterocytes into the duodenum; and from hepatocytes and macrophages into the circulation. This is achieved by hepcidin's binding to the iron channel ferroportin. Ferroportin is the only iron exporter in these iron storage cells and it is rapidly degraded after hepcidin's binding (6). After ferroportin degradation, the retained iron is "trapped" in cytoplasmic ferritin form and unavailable to be used for erythropoesis.

Use of radiolabeled 125 -hepcidin revealed that about $90 \%$ of hepcidin circulates bound to $a_{2}-$ macroglobulin (specific binding) and the rest is bound to albumin (nonspecific binding with nonsaturable kinetics) or unbound. Hepcidin bound to $a_{2}$-macroglobulin seems to be active - it was found to decrease ferroportin expression in cell culture (7). The recent study by Huang et al. showed that serum iron levels are reduced to a significantly greater extent in mice treated with $a_{2}$-macroglobulin-hepcidin complex than in those treated with unbound hepcidin. The researchers suggested that this binding delays hepcidin excretion by the kidney and increases its circulatory half-life and efficacy compared to free hepcidin (unbound ${ }^{125}$ I-hepcidin was significantly increased in the kidney and urine relative to ${ }^{125}$-hepcidin complexed to $\mathrm{a}_{2}$-macroglobulin) (8).

\section{Regulation of hepcidin activity}

Although hepcidin peptide was isolated in 2000, HAMP gene was not discovered until two years later, in 2002 by Nicolas et al., on chromosome 19 (NCBI Gene ID 57817) (9). An inflammatory triggered pathway includes IL- 6 that binds to IL- 6 receptor (IL-6-R) and activates Janus kinase 2/signal transducer and activator of transcription 3 (JAK2) STAT3) signaling to up-regulate HAMP. This activation was also observed in cultures of primary human hepatocytes from micro-inflamed ESRD (10). Very intensively studied inflammatory pathways include members of transforming growth factor- $\beta$ (TGF- $\beta$ ) superfamily (BMPs 2, 4, 5, 6, 7 and 9) that were found to induce BMP signaling by phosphorilation of Sma and Mad related proteins (SMADs). Most of the data was collected on BMP6, which together with activin $B$ binds to bone morphogenic protein receptor (BMP-R) and phosphorilates cytoplasmic SMAD1, 5 and 8 proteins that, together with SMAD4, translocate to the nucleus and stimulate hepcidin expression by interaction with BMP responsive elements on HAMP promoter $(11,12)$. In Bmp6 disrupted mice hepcidin expression was so low that it led to iron overload which could not be compensated by other BMPs. Membrane hemojuvelin (mHJV) was identified as a BMP co-receptor in this pathway. Homozygotes or combined heterozygotes mutations of glycophospatidylinositol(GPI-) anchored mHJV in humans markedly reduce hepcidin expression and cause juvenile hemochromatosis. This mHJV is an important factor in the iron regulatory pathway of hepcidin expression and represents itsconnection to BMP-SMAD pathway. When TR-Fe complex concentrations increase in the circulation, like in hemochromatosis, it binds to transferring receptor 1 (TRF1) and displaces hereditary hemochromatosis protein (HFE) and signals HAMP induction, possibly through in- 
teraction with TFR2. Hepcidin regulation by HFE, which interacts with TFR2 and mHJV to form a "supercomplex" and leads to up-regulation of hepcidin expression via BMP-SMAD signaling, is still not entirely clarified. Use of tagged proteins showed "supercomplex" formation in cell cultures, but their interaction has not been shown in vivo (in mice and humans) and the precise molecular mechanism of HFE and TRF2 role in hepcidin regulation is still under investigation (13). Matriptase-2 (MT-2) is a membrane protease in hepatocytes that acts as a hepcidin suppressor and inhibits the "supercomplex" formation. MT-2 was tested in human and animal models and it was found that MT-2 mutations cause high hepcidin expression and iron deficiency anemia refractory to therapy. MT-2 cleaves $\mathrm{mHJV}$ in hepatocytes and $\mathrm{mHJV}$ cannot act as a BMP co-receptor. Neogenin is a ubiquitous cell surface protein that forms a tertiary complex with MT-2, BMP receptor and HJV thus facilitating MT-2 mediated HJV cleavage. It was found to be essential for HJV function in mice, but this is still to be confirmed in humans (14). Another hepcidin up-regulating mechanism appears to be activated by endoplasmatic reticulum stress, which activates hepcidin promoter gene through the cyclic adenosine monophosphate (cAMP) response elementbinding protein $\mathrm{H}(\mathrm{CREBH})$, a liver-specific transcription factor (15). It physiologically prevents iron utilization and iron overload; his down-regulation was first documented in iron overload disorders most forms of hereditary hemochromatosis (16-19) and later in cases of thalassemia (20). Except hereditary causes for hepcidin down-regulation, such as HFE mutations in hereditary hemochromatosis and mHJV mutation in juvenile hemochromatosis, the most specific evidence on hepcidin suppression were found for MT-2. Other studies identified hypoxia-inducible factors (HIF), HIF-1a and HIF-2a, which presumably have a role in down-regulation of hepcidin in hypoxia. They bind to enhancer element of erythropoietin (EPO) gene and activate its transcription (21). A study on hepatocyte cultures showed that proteolytic cleavage of prohepcidin to hepcidin is not regulated by TR-Fe complex or the HIF pathway (22). Two other research groups found that hepcidin expres- sion was not directly regulated by HIFs $(23,24)$. Thus the effect of HIFs on hepcidin down-regulation is still controversial. One study found that hepatocyte $\mathrm{mHJV}$ was elevated only in chronic kidney disease (CKD) patients undergoing hemodialysis (HD), not in renal transplant recipients or in CKD patients who weren't treated with HD. In this study each of the 3 patient's groups had only 31 patients (25). Molecular mechanisms responsible for the increase in hepcidin concentrations in hypoxia are yet to be clarified. Several studies showed that the induction of erythrocytopoesis causes down-regulation of hepcidin, and not hypoxia or anemia. In cases of bone marrow suppression by citotoxic agents or irradiation, the downregulation of hepcidin does not occur $(26,27)$. Furthermore, when EPO was subcutaneously administered to healthy humans, hepcidin was profoundly suppressed in the next 24 hours (and gradually recovered during the following two weeks), while soluble transferrin receptor and growth differentiation factor-15 (GDF15) remained constant (28). Ashby et al. examined few candidates for bone marrow-derived mediators of hepcidin suppression. EPO was considered to lead to hepcidin suppression by reducing transferrin saturation, but hepcidin decrease in serum precedes the reduction in transferrin saturation (29). A study performed on freshly isolated mice hepatocytes and human hepatocytes (cell line HepG2) showed that hepcidin mRNA was down-regulated by EPO, administered in supraphysiological, therapeutic doses, in a dose-dependent manner. This effect was blocked by anti-EPO receptor (anti-EPO-R) antibody, along with a down-regulation of CCAAT/ enhancer-binding protein a gene (CEBPA gene) mRNA that is responsible for expression of signaling protein C/EBPa (CCAAT/enhancer-binding protein a). Protein C/EBPa binds to HAMP promoter and directly reduces hepcidin expression as a downstream result of EPO binding to EPO-R on hepatocyte surface $(30,31)$ (Table 2). Schematic representation of hepcidin regulation pathways can be found in Figure 2.

Lakhal et al. showed that infusion of iron chelator deferoxamine increases plasma GDF15 in vivo, but the finding was limited by small number of partici- 
TABLE 2. Molecular regulation of hepcidin transcription (15,31).

\begin{tabular}{|c|c|c|}
\hline Regulator & Mechanism of regulation & Result \\
\hline BMP & Binds to BMP receptors on hepatocytes & SMAD-mediated induction of HAMP transcription \\
\hline mHJV & Acts as a BMP co-receptor on hepatocytes & Increases signal for SMAD-mediated HAMP transcription \\
\hline sHJV & Competes with HJV for BMP & Decreases signal for SMAD-mediated HAMP transcription \\
\hline MT-2 & Cleavage of HJV on hepatocytes & Inhibits BMP and SMAD-mediated HAMP transcription \\
\hline IL-6 & Binds to IL-6 receptor on hepatocytes & $\begin{array}{c}\text { Activates JAK2/STAT3-dependent signal pathway to } \\
\text { promote HAMP transcription }\end{array}$ \\
\hline TR-Fe & Binds to transferin receptor 1 or 2 on hepatocytes & Activates ERK 1/2-mediated HAMP transcription \\
\hline HFE & $\begin{array}{l}\text { Binds to transferin receptor } 1 \text { and } 2 \text { on } \\
\text { hepatocytes (competes with TR-Fe) }\end{array}$ & Inhibits activation of ERK $1 / 2$-mediated HAMP transcription \\
\hline $\begin{array}{l}\text { Endoplasmatic } \\
\text { reticulum stress }\end{array}$ & Activates $C R E B H$ in hepatocytes & CREBH binds and activates HAMP promoter gene \\
\hline EPO & Binds to EPO-R on hepatocytes & $\begin{array}{l}\text { Deactivates CEBPA transcription and decreases C/ } \\
\text { EBPa-mediated activation of HAMP promoter }\end{array}$ \\
\hline HIF & 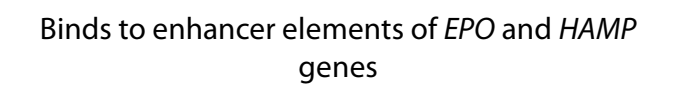 & $\begin{array}{l}\text { Activates transcription of } E P O \text { and deactivates transcription } \\
\text { of HAMP. Reduces hepcidin (?) }\end{array}$ \\
\hline Activin B & $\begin{array}{l}\text { Activates SMAD signaling pathway in } \\
\text { hepatoma-derived cell cultures }\end{array}$ & $\begin{array}{c}\text { Contributes to inflammatory SMAD-mediated HAMP } \\
\text { transcription in vivo (?) }\end{array}$ \\
\hline GDF15 & Induces changes in SMAD (?) & Decreases SMAD-mediated HAMP transcription (?) \\
\hline TWSG1 & Blocks BMP signaling pathway & Decreases SMAD-mediated HAMP transcription (?) \\
\hline
\end{tabular}

BMP - bone morphogenic protein; HAMP - hepcidin gene; mHJV - membrane hemojuvelin; sHJV - solubile hemojuvelin; MT-2 matriptase-2; IL-6 - interleukin 6; JAK2/STAT3 - Janus kinase 2/signal transducer and activator of transcription 3; TR-Fe - transferin-iron complex; ERK 1/2 - extracellular-signal-regulated kinase 1/2; HFE - hereditary hemochromatosis protein; CREBH - CAMP response element-binding protein $\mathrm{H}$; EPO-R - erythropoietin receptor; CEBPA - CCAAT/enhancer-binding protein a (C/EBPa) gene; HIF hypoxia indcibile factor; GDF15 - growth differentiation factor 15; TWSG1 - twisted gastrulation 1.

pants (8 healthy volunteers) and the increase was modest compared to in vitro responses in human cell lines. They investigated GDF15 further and in a study with slightly larger number of subjects ( 21 iron-replete and 22 iron-deficient) found that GDF15 was higher in iron-deficient subjects. GDF15 is a BMP antagonist, but was not elevated in healthy subjects, iron deficiency or reduced hepcidin expression by blood loss (32).

\section{Hepcidin in renal transplant recipients}

\section{The role of hepcidin in pathogenesis of anemia and its significance as biomarker of anemia}

The European TRESAM Survey published in 2003 reported anemia prevalence of $38.6 \%$, and very similar prevalence of $42 \%$ was reported in 10 Euro- pean centers in 2010 (33,34). This makes anemia more prevalent in kidney transplant patients than in GFR-matched CKD-patients. PTA shows two peaks. The early peak (within 3 months after TX) occurs because of low pre-transplant hemoglobin $(\mathrm{Hb})$, blood loss or infection during surgery, aggressive hydration or frequent blood sampling after surgery, delayed graft production of EPO and IS therapy influence (35). The late peak is associated with a decline in kidney function (36-38).

Hepcidin is predominantly produced in liver upon iron overload, hypoxia and inflammation, but kidneys are also involved in the synthesis of hepcidin, as well as in its elimination. Thus hepcidin concentrations are influenced by kidney graft function and post-transplant iron status. Hepcidin synthesis is up-regulated in uremia as in other inflammatory 


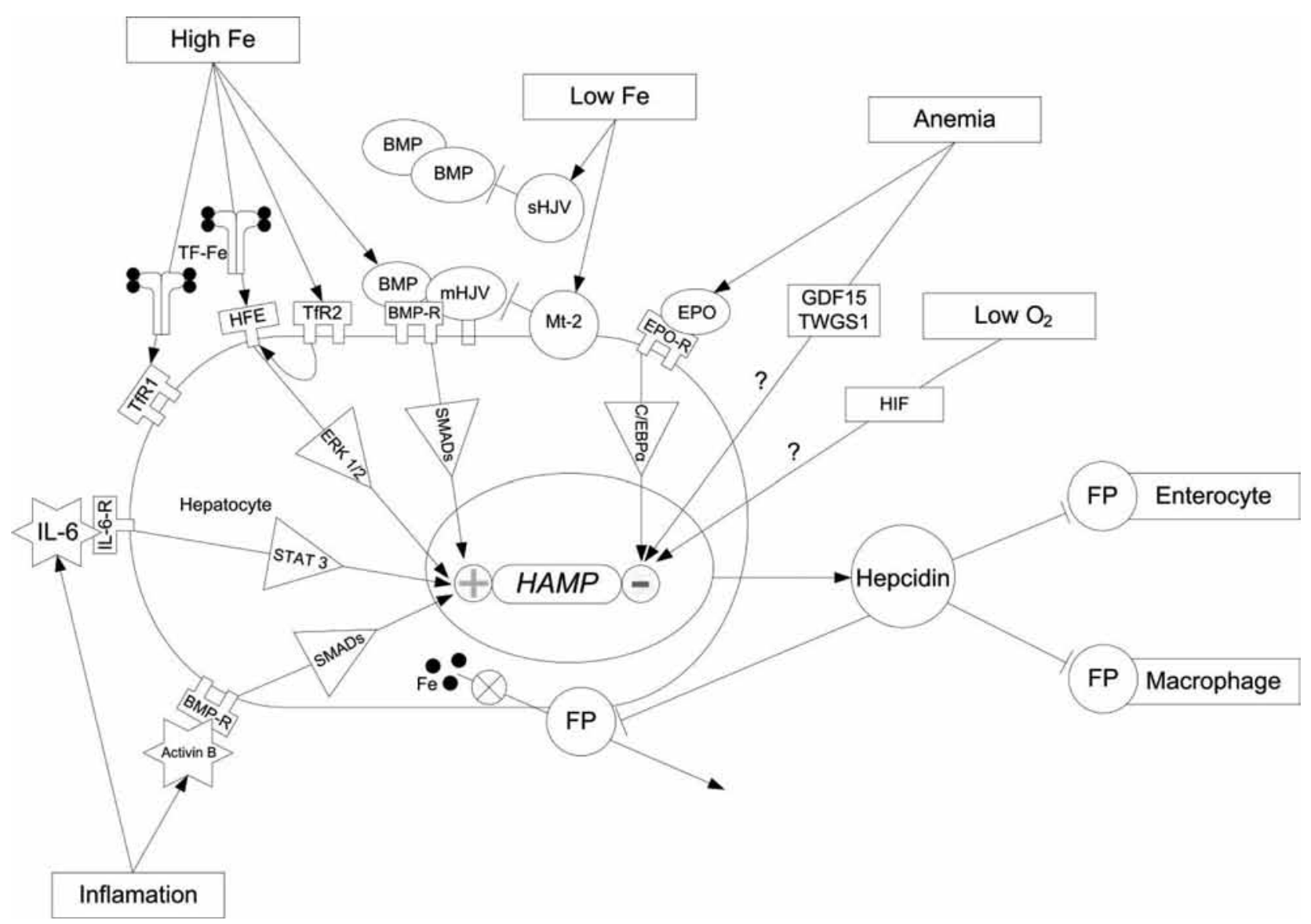

Figure 2. Regulation of hepcidin antimicrobial peptide (HAMP) expression.

Iron abundance (high Fe) induces bone morphogenic proteins (BMPs) binding to their receptor (BMP-R) and SMAD-mediated induction of HAMP. Membrane hemojuvelin (mHJV) is a BMP co-receptor. Matriptase-2 (MT-2) is active in iron deficiency and hypoxia, inhibits BMP signal transmission. Solubile hemojuvelin ( $\mathrm{sHJV}$ ) is cleaved from HJV by furine convertase or type II transmembrane serin protease TMPRSS6. It competes with SHJV in BMP and has a negative effect on BMP signal transmission. High iron concentration causes binding of transferring-iron complex (TR-Fe) to transferrin receptor 1 (TfR1). This binding displaces hereditary hemochromatosis protein (HFE) and signals HAMP induction, through interaction with transferrin receptor 2 (TfR2) and extracellular-signal-regulated kinases $1 / 2($ ERK1/2) signal pathway.

Inflammation stimulates hepcidin production trough two mediators, interleukin-6 (IL-6) and activin B. IL-6 binds to IL-6 receptor (IL6-R) on hepatocyte and activates Janus kinase 2/signal transducer and activator of transcription 3 (JAK2/STAT 3) signal pathway. Activin $B$ binds to BMP-R and activates SMADs. Both inflammatory mediators have a positive effect on HAMP expression. Anemia causes an increase in production of erythropoietin that binds to erythropoietin receptor (EPO-R) and down-regulates expression of signaling protein CCAAT/enhancer-binding protein a (C/EBPa) and hepcidin. The mechanisms of hypoxia inducible factor (HIF), growth differentiation factor 15 (GDF15) and twisted gastrulation (TWSG) as HAMP modulators is still controversial.

states. Przybylowski et al. conducted a well designed study including 170 renal allograft recipients and 168 patients after orthotopic heart TX, with very similar IS therapy used and no signs of inflammation or rejection. The prevalence of PTA was $37 \%$ among kidney transplant patients and $34 \%$ among heart transplant patients. Anemic kid- ney transplant patients, as well as anemic heart transplant recipients, exhibited significantly higher hepcidin when compared to their non-anemic counterparts. Based on their results it seems that the observed PTA and impaired kidney function (also present after heart TX), and not inflammation, were the leading causes of hepcidin elevated 
concentrations since eGFR and ferritin, but not hsCRP were found to be predictive of hepcidin concentrations (39). Interestingly, the authors concluded that it was plausible that hepcidin is not a pathogenic factor for PTA among heart or kidney transplant recipients. The role of hepcidin in pathogenesis of anemia of chronic disease is very well documented, especially in ESRD, since it is an important contributor to morbidity and mortality in ESRD.

\section{The role of hepcidin in resistance to erythropoiesis-stimulating agents (ESA) after renal transplantation (TX)}

High plasma hepcidin concentrations decrease iron availability to bacteria and cancer cells leading to anemia of chronic disease, despite the therapy with ESA (e.g. cancer, autoimmunity or chronic infection) (40). A functional iron deficiency can be often observed in renal transplant recipients - iron stores are adequately filled (normal or high ferritin levels and transferrin saturation at $20 \%$ or less), but iron is unable to be released from its stores, and subsequently erythrocytopoesis is inadequate. Since clinicians treat PTA with ESA, hepcidin could be used to clarify the often found disbalance in iron metabolism and resistance to ESA in the post-transplant period. Therefore, hepcidin could become an important tool to predict ESA responsiveness and to guide treatment with ESA and intravenous iron. The prediction of ESA resistance would be an important step forward in treating anemia after renal TX. Two cohort studies have reported an association between higher doses of ESA and mortality $(41,42)$, as well as the results of randomized controlled trials that reported an increased mortality or morbidity in patients who were targeted to high $\mathrm{Hb}$ concentrations $(43,44)$.

\section{Hepcidin in relation to other biomarkers of anemia}

Many studies showed an association between hepcidin and ferritin, either by correlation of the two parameters or ability of ferritin to predict hepcidin by multiple regression analysis. Indeed, hepcidin and ferritin have some common characteris- tics - their plasma concentration is decreased in iron deficiency and increased in inflammation (but not specificaly, as they are both elevated in various cancers), and can be used in treating anemia after renal TX. In this sense, hepcidin shows some advantages over ferritin - it reflects iron availability and not just iron stores, and better reflects the status of iron homeostasis than single parameters such as transferrin saturation, solubile transferrin receptors and CRP (45). A study was done by Kato et al. to evaluate hepcidin and prohepcidin as potential predictors of ESA responsiveness in a small number of CKD patients on HD. Neither hepcidin nor prohepcidin were found to be good predictors of ESA resposiveness (46). Besides the small number of subjects (only 75), the limitations of this study were that hepcidin was measured only semiquantatively (peak intensity of serum hepcidin-25 by SELDI-TOF MS). Multiple regression analysis did not show statistically significant association between prohepcidin and hematopoietic parameters, but prohepcidin had a weak relationship with ESA dosage. The biggest disadvantage of using prohepcidin is that it is not an active form of hepcidin, and there is no clear relationship between prohepcidin and hepcidin concentration in circulation, since available part of hepcidin degrades to iron-regulatory inactive isoforms (hepcidin-20 and -22). Malyszko et al. conducted a study that enrolled 70 subjects after renal TX and correlated hepcidin to other renal markers. Hepcidin was associated with total protein, creatinine, ferritin, eGFR (calculated by MDRD equation) and time after TX. Multiple regression analysis showed that only eGFR and ferritin could be considered as predictors of hepcidin. Since in healty subjects hepcidin showed no association with creatinine and eGFR, it could be assumed that hepcidin is accumulated in renal insufficiency CKD and could be used as a marker of it (47). The limitation of hepcidin determination in this study was the determination by ELISA, which is not completely specific for hepcidin-25 (hepcidin-20 and -22 can also be measured). When compared to other markers of iron status, such as iron, ferritin and transferrin saturation, hepcidin 25 seems to be the most sensitive indicator of iron absorption. This is an indica- 
tion that in the future hepcidin could substitute conventional assays for measuring iron status. The only drawback is that hepcidin is limited to noninflammatory conditions, but this concerns also other tests for monitoring iron concentrations.

\section{Elimination of hepcidin by kidneys}

Since hepcidin is a very small peptide, it is filtered freely in the glomeruli and almost completely reapsorbed in the tubules (fraction extraction of hepcidin estimated in patients with hemochromatosis and thalassemia was found to be less than $3 \%)(48,49)$. Thus, it is clear that hepcidin is eliminated by the kidneys, but it is still unclear which process is determining the rate of hepcidin elimination - filtration, reabsorption, local production and/or degradation. A study with limited number of participants has provided evidence that tubular reabsorption (via megalin-mediated endocytosis) and local production in distal kidney tubules may contribute to urine hepcidin concentrations. This production is stimulated by monocytes in inflammatory conditions, but monocytes are also capable of producing hepcidin, at least in cell cultures, when stimulated with pro-inflammatory cytokine. Furthermore, an increase of urine hepcidin-25 was considered a potential marker for tubular degradation in patients with CKD since it seems to accumulate in plasma and, according to Peters et al., it is due to inadequate tubular reabsorption in patients with biopsy proven tubular disease (similar observation was found earlier for prohepcidin by Taes et al.) $(50,51)$. But the effect of uremia and how residual renal function determines hepcidin clearance is yet to be determined. Studies on a larger number of human subjects are necessary to confirm if inflammation after renal TX causes distal tubules and/or monocytes in kidney to produce hepcidin, determine the extent of this production and its clinical value. If local hepcidin production would prove to be valuable in monitoring the graft function, that would justify the determination of hepcidin concentrations in urine samples as markers of kidney inflammation and possibly predictors of post-transplant tubular degradation and renal rejection.

\section{Hepcidin and kidney disorders}

As an acute phase protein, hepcidin is induced in inflammation. The subclinical inflammation often found in patients with CKD limits its use as a marker of renal function. Since study by Peters at al. associated serum hepcidin with tubular degradation in CKD (hepcidin inversely correlated to eGFR), serum and urine hepcidin was investifgated as a marker of acute kidney injury (AKI). Urinary hepcidin was found to be a protective marker for AKI after cardiopulmonary bypass surgery. Interestingly, a smaller rise in hepcidin's urine concentrations implied a greater renal injury (resulting in lesser hepcidin reabsorption from primary filtrate) and was associated with higher risk of AKI (52). Two papers published by Ho et al. found that increased urine hepcidin concentrations indicated lower risk of developing AKI after cardiac surgery, and this was confirmed in a larger study with 100 subjects. The increased local production of hepcidin in kidney is attributed to the prevention of oxidative damage induced by free iron in AKI (hepcidin binds $\left.\mathrm{Fe}^{2+}\right)(53,54)$. It was found that in patients with lupus nephritis changes in urine hepcidin-25 and -20 predict renal flares. Hepcidin- 25 serum concentration decreased in a renal flare and hepcidin-20 increased 4 months before a renal flare (this urine proteomics study was limited to 25 samples) (55). Lack of evidence regarding clinical significance of urine hepcidin concentration after renal TX renders urine hepcidin use in monitoring controversial. CKD is associated with increased serum hepcidin and it contributes to anemia and ESA resistance. If ESA resistance could be predicted or even abolished by hepcidin monitoring or reduction, it would mean better management of CKD patients, and need for lower doses of ESA to correct anemia, since higher doses carry a risk of dose-related side effects. It seems that hepcidin reflects status of chronic (in CKD) and acute inflammation (in $\mathrm{AKI}$ ), but by different mechanisms. In CKD hepcidin is up-regulated in the liver and in AKI presumably in the kidney, and therefore it is necessary for future research to measure hepcidin in serum and urine. Since hepcidin is an inflammatory inducible peptide, it can only be used as an 
indicator of renal function changes in cases of CKD without acute inflammation. In case of AKI, hepcidin rise in serum is caused by increase of TR-Fe and IL-6 that induce hepcidin expression, thus it can act in preventing iron oxidative damage. But why a post-surgically better functioning kidney tubules (not prone to subsequent AKI) do not completely reabsorb hepcidin and degrade it is still unknown.

\section{The influence of immunosuppressive therapy}

Immunosupressive therapy (IS) after renal TX contributes to the development of anemia through different mechanisms. Antimetabolites, such as azathioprine, mycophenolic acid (MPA) and mycophenolate mofetil (MMF), have a direct effect on bone marrow cells and their suppression may aggravate anemia $(39,56)$. In a cohort study with 878 renal transplant recipients it was reported that $58 \%$ of them on MMF were anemic and presented with lower GFR than patients not given MMF. A possible confounding factor was that all patients on treatment with ESA were classified as anemic, irrespective of hemoglobin concentrations. Perhaps those patients would be better classified by hemoglobin concentration. The effect of this potential classification error is not large, since only 68 adults were stimulated by recombinant EPO and $75 \%$ stayed anemic despite therapy (57). In a smaller study on 170 renal transplant recipients, those treated with MMF or MPA showed lower hemoglobin compared to patients not treated with MMF or MPA. Similar observations were found in patients treated with mTOR inhibitors sirolimus or everolimus, which can cause myelosuppression and anemia particularly when administered together with MMF. Maiorano et al. conducted a study that included 42 biopsy-proven chronic allograft nephropathy patients randomized to receive cyclosporine or sirolimus. Based exclusively on hepcidin results, the authors suggested that sirolimus interferes with iron metabolism and that in this case PTA does not present the features of inflammation-related anemia, since serum hepcidin was similar in the two groups after therapy rand- omization. However, their observation is based only on hepcidin, ferritin and transferrin concentrations, not on other inflammatory markers, and the study in general is of limited power due to a small number of patients and the fact that it measured prohepcidin and not the active hepcidin-25 (58). Thaunat et al. investigated CRP, IL-6 and IL-10, and reported an opinion opposite to Maiorano: sirolimus induces a defective IL-10-dependent autoregulation of inflammation, thereby inducing anemia, in cases of late introduction of sirolimus (59). A retrospective study performed on 93 allograft recipients with sirolimus-induced anemia and microcytosis showed no impact of MMF on the occurrence or severity of PTA (60). In assessing the influence of IS therapy on hepcidin anemia after renal TX first thing that should be made clear in future studies is which IS (if any) can be associated with subclinical inflammation that could cause a rise in hepcidin (and lead to functional iron deficiency and impaired gastrointestinal absorption of iron). Hepcidin measurement in such anemic patients might help prove IS role in PTA pathogenesis. This mechanism seems more likely for mTOR inhibitors, at least for now. As far as MMF/MPA therapy is concerned, it seems that anemia is caused by IS effect on bone marrow, rather than the inflammatory effect that could cause a hepcidin rise.

\section{Hepcidin determination}

The small size of hepcidin and its different isoforms made it a challenge to produce a specific immunoassay and therefore hepcidin was considered a hormone very difficult to measure. Radioimmunoassay (RIA) is very sensitive and specific immunoassay method that was first considered for hepcidin measurement. It uses a competitive principle - radioactive ${ }^{125}$ | bound to tyrosine or histidine of synthetic hepcidin-25 (in known amount) is mixed with serum from patient containing an unknown quantity of hepcidin. The radioactive and non-radioactive hepcidin molecules compete for polyclonal rabbit anti-hepcidin-25 antibody. Immunocomplexes are separated using a secondary antibody-PEG assisted separation and quantified by radioactivity measurement. Since this 
method has been suppressed by non-radioactive immunoassays (ELISA), the only commercially available RIA test is "Hepcidin-25 RIA kit" (Bachem, UK). Manufacturer has declared measurement range of $0.1-13 \mathrm{ng} / \mathrm{mL}$, using the hepcidin- 25 as standard. Ashby et al. evaluated this assay and found it to be linear up to $200 \mathrm{ng} / \mathrm{mL}$, with a detection limit of $0.6 \mathrm{ng} / \mathrm{mL}$, intra-assay precision $7.2 \%$ (at $3 \mathrm{ng} / \mathrm{mL}$ ) and $5.8 \%$ (at $35 \mathrm{ng} / \mathrm{mL}$ ), and inter-assay precision $7.6 \%$ (at $3 \mathrm{ng} / \mathrm{mL}$ ) and $6.7 \%$ (at $35 \mathrm{ng} / \mathrm{mL})$. Analytical recovery was $98 \%(5 \mathrm{ng} / \mathrm{mL})$ and $97 \%$ (40 ng/mL). Cross-reactivity with synthetic hepcidin-20 was observed, and it was 9.6\% (200 $\mathrm{ng} / \mathrm{mL}$ ). There was no cross-reactivity with prohepcidin (25). A 10-20\% cross-reactivity with hepcidin-20 and -22 was found (61).

The first ELISA for serum hepcidin was developed and evaluated by Ganz et al. It was a competitive assay with biotinylated hepcidin-25 (Intrinsic LifeSciences, La Jolla, CA, USA) as a tracer and a synthetic hepcidin was used for standard curve measurement. No accuracy or recovery data was reported, but intra-assay precision of 5-19\% and inter-day precision of $12 \%$ was found. Measurement range was declared at $5.6-4000 \mathrm{ng} / \mathrm{mL}$, but precision data indicate that the detection limit may be closer to $50 \mathrm{ng} / \mathrm{mL}$. The extent of cross-reactivity with hepcidin-20 and -22 has not been stated for this assay, and should be examined in the future. Their evaluation study enrolled 114 healthy volunteers and showed a diurnal increase of serum hepcidin at noon and 8 p.m. compared with 8 a.m., and a transient rise as a response to iron ingestion. Using this immunoassay they found normal values of hepcidin to be $29-254 \mathrm{ng} / \mathrm{mL}$ in men and 17 $286 \mathrm{ng} / \mathrm{mL}$ in women (48). The same ELISA test was later reported to have median hepcidin concentrations of $73 \mathrm{ng} / \mathrm{mL}$ for healthy subjects and $270 \mathrm{ng} / \mathrm{mL}$ for CKD patients. Researchers concluded that their findings are in agreement with those reported by Ashby et al. for hepcidin levels in CKD patients using radioimmunoassay (62), which determined normal range for healty subjects at 2 - 56 $\mathrm{ng} / \mathrm{mL}$ with median hepcidin concentrations of 11 ng/mL. In CKD patients, hepcidin concentrations ranged from $3-153 \mathrm{ng} / \mathrm{mL}$ with a median $26.5 \mathrm{ng} /$ $\mathrm{mL}$ (25). Considering the very wide range, the method would probably be better suited for hepcidin measurement in renal transplant recipients and CKD patients rather than healthy subjects, since they are expected to have higher hepcidin. Precision must be taken into account, considering that precision data indicates that the detection limit of competitive ELISA could be much higher than manufacturer states $(50 \mathrm{ng} / \mathrm{mL}$, and not 5.6 $\mathrm{ng} / \mathrm{mL}$ ), which is in range with hepcidin concentrations expected in healthy subjects. Besides the difference in calibration, antibody affinity for different isoforms, binding to $a_{2}$-macroglobulin and albumin, circadian rhythm and lack of standardization in blood collection may also contribute to variations in hepcidin concentration in healthy population.

Commercially available kit "Hepcidin-25 (bioactive) ELISA" (DRG International Inc., Springfield, NJ, USA) uses a sandwich principle with monoclonal antibodies against hepcidin- 25 in serum/plasma, with no detectable cross-reactivity to prohepcidin and no reports on cross-reactivity to hepcidin-20 and -22 . This presents a problem when measuring hepcidin in patients with ESRD since they have higher hepcidin-20 and -22 concentrations in serum (63). The manufacturer declares an assay range of $0.35-80 \mathrm{ng} / \mathrm{mL}$, with possible dilution up to 100 -fold for hepcidin concentrations higher than dynamic range. The mean intra-assay coefficient of variation (CV) stated is $5.1 \%$ and inter-assay CV $12.7 \%$. DRG also offers a "Pro-hepcidin ELISA kit" for prohepcidin measurement in serum, plasma and homogenisated tissue. Its declared detection range is $3.95-1000 \mathrm{ng} / \mathrm{mL}$, and the same intra- and inter-assay CV $<10 \%$ (http://www.drginternational.com). These assays have not yet been evaluated in the routine clinical setting.

Kulaksiz et al. have also developed an ELISA method for serum prohepcidin quantification. It uses an anti-hepcidin rabbit antibody for prohepcidin and $\mathrm{N}$-terminally biotinylated prohepcidin as a competitor and streptavidin-peroxidase to facilitate detection. This assay is reported to be very reproducibile and sensitive, but its most important disadvantages are the detection of the pro-peptide region of hepcidin, the lack of clear correlation with active hepcidin- 25 and no correlation with 
iron status markers (e.g. iron, ferritin, transferrin) (64-66).

Mass spectrometry is useful for quantifying small molecules and peptides. The molecule undergoes ionization and fragmentation and the generated charged fragments are recognized and measured by their mass-to-charge ratios. For hepcidin measurement several technological approaches have been used - surface enhanced laser desorptiontime of flight mass spectrometry (SELDI-TOF MS), MALDI-TOF MS and liquid chromatography tandem mass spectrometry (LC MS/MS). The main advantages of these methods are the separation of hepcidin isoforms and quantification of only hepcidin-25 without interferences of hepcidin-20 and -22 , and quantification can be done in serum and urine samples. Using SELDI-TOF MS with desAsphepcidin (hepcidin-24) as internal standard, Swinkels et al. showed good precision ( $<10 \% \mathrm{CV})$, but a difference in desAsp-hepcidin and hepcidin-25 binding properties that may indicate that this is not the best choice of internal standard (49). Others used isotope-labeled hepcidin as internal standard in SELDI-TOF MS with good intra-day $(<$ $10 \%)$ and inter-day $(<20 \%)$ precision, as well as limit of detection of $10 \mathrm{ng} / \mathrm{mL}$ (67). Those studies had no accuracy and recovery data presented. Kemna et al. evaluated SELDI-TOF MS for quantification of hepcidin isoforms in serum and urine in 73 subjects with different iron status, from iron deficiency to hereditary hemochromatosis. They used synthetic human hepcidin-25 for calibration. Interestingly, they found all three isoforms in urine, but no hepcidin-22 in serum, which supports the evidence that hepcidin-20 and -25 are produced in hepatocytes and released in blood stream, while hepcidin-22 is a urinary degradation product of hepcidin-25 (68). MALDI-TOF MS with isotope-labeled hepcidin as internal standard, but only for urine samples, because serum samples displayed poor peak resolution. This method shows limit of detection $1-300 \mathrm{nmol} / \mathrm{L}$ (2.8 - 836.9 ng/mL) with intra-assay CV $12.1 \%$ and inter-assay precision $13.2 \%$ (66).

LC MS/MS was first used in hepcidin quantification by Murphy et al., after reverse solid phase extraction. Calcitonine gene-related peptide was used as internal standard. The method showed good ac- curacy and precision and a limit of quantification of $1.0 \mathrm{ng} / \mathrm{mL}$ (69). Recent methods that used synthetic stable isotope-labeled hepcidin as internal standard were in concordance, with limits of quantification from $1.1-2.5 \mathrm{ng} / \mathrm{mL}$ and upper limits between 159 and $500 \mathrm{ng} / \mathrm{mL}$. They showed good inter-day precision (CV < 10\%) $(70,71)$. Li et al. used 60 control samples and 50 CKD patients, and found hepcidin means for them to be $10 \mathrm{ng} / \mathrm{mL}$ and $99 \mathrm{ng} / \mathrm{mL}$, respectively. This method was validated to FDA criteria for bioanalytical assays (70). Study that used standardized serum and urine hepcidin sampling showed reference values in healthy subjects to be 0.77 to $200 \mathrm{nmol} / \mathrm{L}$ for urine, when measured by LC-MS/MS, with a coefficient of renal excretion ranging from 0.1 to $16.4 \%$. The serum reference values were $0.48-100 \mathrm{nmol} / \mathrm{L}$, in agreement with that obtained by Li et al. (72). A short overview of hepcidin measurement methods and their characteristics is presented in Table 3.

Studies evaluating hepcidin concentrations in CKD found elevated concentrations in HD patients compared with healthy volunteers, but absolute values of serum hepcidin varied up to 10-fold depending on the assay $(25,48,62,66,73,74)$. On the other hand, a few found hepcidin concentrations to be lower after HD $(63,75)$. These contradictory results must be researched in the future and the effect of HD should also be taken into account. Also, an ELISA method should be further improved to detect only free hepcidin-25. In fact, the lack of standardization in hepcidin testing, as well as the lack of specificity for free, total or bound hepcidin (i.e. to $a_{2}$-macroglobulin), have led Kroot et al. to initiate a round robin on hepcidin serum and urinary quantification. They sent 12 replicates of samples, 8 urine samples and 7 plasma pool samples with a wide range of hepcidin from healthy subjects and added synthetic hepcidin-25, to be measured in various laboratories by 8 different methods (competitive RIA, MALDI-TOF MS, two SELDI-TOF MS methods, two LC-MS/MS and two competitive ELISA methods). ELISA methods showed higher hepcidin concentrations compared to LC-MS/MS method (in urine hepcidin means up to 11-fold and SD up to 27-fold and in serum hepcidin means up to 8 -fold and SD up to 30 -fold). An- 
TABLE 3. Comparison of methods for hepcidin determination.

\begin{tabular}{|c|c|c|c|c|}
\hline Method & $\begin{array}{l}\text { Sensitivity } \\
\text { (ng/mL) }\end{array}$ & Specificity & Main feature & Limitation \\
\hline $\begin{array}{c}\text { RIA } \\
\text { (Hepcidin-25 RIA Kit, } \\
\text { Bachem) (61) }\end{array}$ & 0.1 & $\begin{array}{l}10-20 \% \text { cross reactivity with } \\
\text { hepcidin- } 20 \text { and }-22\end{array}$ & $\begin{array}{c}\text { High sensitivity; } \\
\text { Low intra- and inter-assay CV } \\
(<8 \%)\end{array}$ & Radioactive marker \\
\hline $\begin{array}{l}\text { Competitive ELISA } \\
\text { (Ganz et al.) (48) }\end{array}$ & 5.6 & $\begin{array}{l}\text { Cross reactivity with } \\
\text { hepcidin- } 20 \text { and }-22 \text { not } \\
\text { evaluated }\end{array}$ & $\begin{array}{l}\text { Wide measurement range (up } \\
\text { to } 4 \mu \mathrm{g} / \mathrm{mL} \text { ) }\end{array}$ & $\begin{array}{l}\text { High imprecision at < } \\
50 \mathrm{ng} / \mathrm{mL} \text { (not suitable } \\
\text { for healthy subjects) }\end{array}$ \\
\hline $\begin{array}{l}\text { Hepcidin-25 (bioactive) } \\
\text { ELISA (DRG) (http://www. } \\
\text { drg-international.com) }\end{array}$ & 0.35 & $\begin{array}{l}\text { No detectable cross reactivity } \\
\text { with prohepcidin }(0.04 \%) ; \\
\text { No data on cross reactivity with } \\
\text { hepcidin- } 20 \text { and }-22\end{array}$ & $\begin{array}{c}\text { Low intra-assay CV (5.1\%) and } \\
\text { inter-assay CV (12.7\%) }\end{array}$ & $\begin{array}{c}\text { Serum/plasma } \\
\text { determination only }\end{array}$ \\
\hline SELDI-TOF MS (67) & 10 & Specific for hepcidin-25 & $\begin{array}{l}\text { In agreement with } \\
\text { competitive ELISA (Ganz } \\
\text { et al.) for mean hepcidin } \\
\text { concentrations in healthy } \\
\text { subjects }\end{array}$ & $\begin{array}{l}\text { No standardization; no } \\
\text { internal standard }\end{array}$ \\
\hline MALDI-TOF MS (66) & 2.8 & Specific for hepcidin-25 & $\begin{array}{l}\text { High accuracy }(90-110 \% \\
\text { recovery); } \\
\text { Small sample volume (5 } \mu \mathrm{L} \text { of } \\
\text { urine) }\end{array}$ & $\begin{array}{l}\text { Urine determination } \\
\text { only }\end{array}$ \\
\hline LC-MS/MS (70) & 2.5 & Specific for hepcidin-25 & $\begin{array}{l}\text { Good inter-assay precision } \\
\qquad(\mathrm{CV}<10 \%) ; \\
\text { Validated to FDA criteria }\end{array}$ & $\begin{array}{c}\text { Matrix of standards } \\
\text { does not mimic } \\
\text { human serum (rabbit } \\
\text { serum used) }\end{array}$ \\
\hline
\end{tabular}

RIA - radioimmunoassay; CV - coefficient of variation; ELISA - enzyme-linked immunosorbent assay SELDI-TOF MS - surface enhanced laser desorption-time of flight mass spectrometry; MALDI-TOF MS - matrix assisted laser desorption ionization-time of flight mass spectrometry; LC MS/MS - liquid chromatography tandem mass spectrometry.

alytical variations for these methods were found to be generally low and similar for all methods (76). This huge difference in ELISA and LC-MS/MS hepcidin measurement could be due to the fact that ELISA lacks the sensitivity to distinguish hepcidin-25 from hepcidin-20 and -22 . Therefore, in case of hepcidin determination introduction in routine laboratory practice, patients should be monitored exclusively using the same, possibly standardized, method. Before commercial hepcidin ELISA can be implemented in routine laboratory practice, cross reactivity for hepcidin-20 and -22 should be evaluated by an independent party. If MS based methods will become routinely used, despite their expensive and time-consuming nature, a few criteria should be agreed upon: a standard internal standard, commutable calibrator that mimics human matrix and adequate quality con- trol. In light of hepcidin measurement standardization we strongly recommend this be addressed in future studies.

\section{Potential therapeutic use of hepcidin}

Hepcidin agonists and antagonists have been designed in order to modulate iron metabolism. Hepcidin agonists are designed to treat iron overload in hereditary hemochromatosis and thalassemia in order to avoid currently used treatment with phlebotomies and their side effects. Treatments like injection of BMP6, oligonucleotids or small interfering RNA against Tmprss 6 mRNA and minihepcidin (PR65) showed results in decreasing hepcidin concentrations and iron overload in mouse models of hereditary hemochromatosis and/or thalassemia. Minihepcidin is a lipophilic 
peptide that contains 9 aa of the hepcidin's N-terminus which are important for its activity (77). MT2 , as the strongest inhibitor of hepcidin, has been targeted by antisense oligonucleotides against its mRNA (Tmprss6 mRNA) or small interfering RNA (siRNA) against Tmprss mRNA. Injection of sHJV and HJV antisense oligonucleotides selectively inhibited BMP induction of hepcidin expression (78).

The search for optimal treatment for anemia of chronic disease gave even more candidates that showed successful in decreasing hepcidin. Heparin, and his subsequently developed non-anticoagulant forms that bind to BMPs, showed promise in blocking hepcidin transcription and decreasing hepcidin plasma concentration after intravenous injection in mice. Similar approaches have been tried with injections of dorsomorphin and its derivate LDN-193189, which bind to BMP-R and act as inhibitors of BMP-mediated hepcidin transcription pathway $(78,79)$. Injections of BMP and IL- 6 had showed the same effect, but to a different extent injection of BMP-2, $-4,-5,-6,-7$ and -9 showed a hepcidin mRNA increase up to 1000-fold, while IL-6 initiated an increase of only 3.3-fold (80). Antihepcidin was used for hepcidin neutralization and hepcidin mRNA suppression in a mouse model of disease. This treatment was able to increase iron and hemoglobin and overcome anemia of chronic disease (81). Treatment with antibodies such as anti-IL-6 receptor antibody (tocilizumab) was the first potential therapeutic tested on humans and it improved anemia of inflammation in multicentric Castleman disease $(82,95)$. Spiegelmer NOX-H94, non-immunoreactive L-oligoribonucleotide that binds human hepcidin with high affinity (83), and anticalins that bind human hepcidin were used to block hepcidins target ferroportin or hepcidin itself. Anti-ferroportin antibodies and anticalin PRS-080 are in phase I of clinical trials $(84,85)$. Lowering HAMP expression by these or similar mechanisms in humans could increase iron release form stores and help with recovery of anemia patients (Table 4).

\section{Final considerations}

This review is the first one that focuses on hepcidin in renal TX recipients. Specific topics regarding management of renal transplant recipients have been addressed, such as IS therapy influence on PTA and hepcidin, and the role of hepcidin in resistance to ESA. We addressed hepcidin at a molecular, biochemical and clinical level. In inflammation hepcidin gene is induced by IL-6 (via JAK2/ STAT3 signal pathway), as well as BMP6 (via pSMAD1/5/8 and SMAD4 pathway) (10). The resulting effect is the unavailability of iron supplies to microorganisms with high-affinity iron-binding siderophores that make them able to use iron from the host's transferrin. mHJV was identified as a BMP co-receptor in hepcidin's expression signaling pathway. MT2 is a hepcidin suppressor, as it binds mHJV on hepatocytes and stops its BMP coreceptor activity. Homozygotes or combination heterozygotes mutations of $\mathrm{mHJV}$ in humans markedly reduce hepcidin expression and cause juvenile hemochromatosis type $2 \mathrm{~A}$, whereas mutations in HAMP cause juvenile hemochromatosis type 2B (87). Besides hemochromatosis and thalassemia, the hereditary causes for hepcidin downregulation, later studies identified hypoxia-inducible factors - HIF-1a and HIF-2a as a possible downregulators of hepcidin in hypoxia. Some researchers found that HIF-1a subunit binds to enhancer element of EPO gene activating its transcription, but also seems to bind to enhancer element of HAMP gene and down-regulates it (21). Others claim that HIF-2a exclusively regulates EPO gene, based on exspresion studies on hepatocytes and immunohistochemical studies that localized Hif-2a but not Hif-1a to EPO-producing renal cells (88). This down-regulation mechanism is still controversial, since there have been some studies claiming that only erythropoietic activity suppresses hepcidin expression, rather than it being regulated by HIFs in hypoxia $(26,27)$. Molecular mechanism for hepcidin plasma increase in hypoxia or anemia should be further investigated. Other potential down-regulators as GDF15 and TWSG1 also seem promising in further clarifying hepcidin regulation. They are released by erythroid precursors in some iron-loading anemias. TWSG1 expression is increased in thalassemic mice during early erythroblast maturation (suggested mechanism is inactivation of BMP/SMAD activation of HAMP). High 
TABLE 4. Potential therapeutics for hepcidin regulation and their effect $(15,28,77-86)$.

\begin{tabular}{ccc}
\hline Target molecule & Potential therapeutic substance* & Effect \\
\hline BMP6 & Anti-BMP6 & Decrease in hepcidin \\
Injection of BMP6 & Incease in hepcidin \\
Decrease in hepcidin
\end{tabular}

*The substances listed above were tested only on animal models (murine, cynomolgues monkey and zebrafish), hepatoma cell cultures (HepG2 cells) or are in the beginning of clinical trials. Only anti-IL-6 was tested on humans in a multicentric study. BMP6 - bone morphogenic protein 6; anti-BMP6 - antibody against BMP6; BMP-R - bone morphogenic protein receptor; sHJV solubile hemojuvelin; MT-2 - matriptase 2; Tmprss6 - gene for MT-2; siRNA - small interfering RNA; STAT3 - signal transducer and activator of transcription 3; IL-6-R - interleukin 6 receptor; anti- IL-6-R - antibody against interleukin 6 receptor.

GDF15 concentrations can suppress HAMP in cell models, but the underlying molecular mechanism has not yet been characterized (89). A potential up-regulator activin $B$ has been found to have effect on SMAD-mediated regulation of HAMP transcription in hepatoma-derived cell cultures but that is jet to be confirmed in vivo (90).

Up to $90 \%$ of circulating hepcidin is bound to $a_{2}-$ macroglobulin, and this complex was shown to reduce iron concentrations to a significantly greater extent than free hepcidin. It is argued that the reason is slower hepcidin urine excretion, but this remains to be confirmed in humans (8). In renal transplant recipients this could be of great significance, since their renal excretion is limited by graft function. In case of degrading graft function plasma hepcidin elevation could theoretically contribute to PTA and resistance to ESA treatment, as it was shown in CKD. EPO has been identified as a hepcidin suppressor, but it is unclear if it is ineffec- tive in hepcidin suppression in ESA-resistant PTA or his suppression is simply not adequate enough compared to other active hepcidin up-regulating mechanisms. In renal recipients with worsening graft function hepcidin is expected to be up-regulated because of uremia and/or subclinical inflammation (by IL-6 activation of JAK2/STAT3-mediated HAMP transcription). Another reason for plasma hepcidin increase is iron substitution therapy after renal TX that has a positive effect on HAMP transcription by BMPs. It also increases TR-Fe displacement of HFE from TRF1 and formation of HFETRF2-mHJV supercomplex that induces HAMP. Could that lead to higher hepcidin serum concentration and cause PTA? Could it be in that extent that it could become a marker of kidney function or predictor of PTA? At this point of research and with different measurements challenges hepcidin faces it is still too early to say. 
Hepcidin has been shown to be a good marker of iron status after renal TX and it is superior to current markers of iron homeostasis (iron, transferin saturation and solubile transferin receptor) (45). Many studies have reported considerable hepcidin and ferritin asociation in anemia $(39,47,58,91)$, but with one important advantage of hepcidin instead of reflecting how much iron is circulating or stored, it is the most sensitive indicator of iron absorption and reflects how much iron is accessible under current conditions (inflammation, iron concentration, anemia and hypoxia). Because hepcidin serum concentration is regulated by all of these processes, hepcidin gives a better insight into complex iron homeostasis. Since hepcidin acts in preventing iron oxidative damage in inflammation (as seen in AKI), its' use should be limited to non-inflammatory states (similar to other acute phase proteins), at least when one is assessing renal TX recipients for possible chronic rejection (recipients without subclinical inflammation can be selected by determining high sensitive CRP). On the other hand, researchers that studied hepcidin after cardiac surgery found increased urine hepcidin protective for AKI (52). This justifies further research on inflammation induced local production of hepcidin in kidneys and possibly designing a study that accesses diagnostic abilities of urine hepcidin in predicting AKI in renal TX recipients.

In addition to its correlation with ferritin, hepcidin correlates with creatinine, total protein and eGFR (calculated by MDRD) in patients after renal TX, but only ferritin and eGFR could be used as predictors of hepcidin (47). It is clear that high hepcidin concentration contributes to PTA, but additional research is needed to determine if hepcidin can be used to predict ESA resistance in renal TX recipients. Since iron and recombinant EPO are often used for PTA treatment, future studies will also have to assess the effect of each of these therapeutics on hepcidin regulation, since high iron induces HAMP expression and EPO decreases it.

Research on effect of IS therapy on hepcidin is limited to a single study by Maiorano et al. that randomized patients to receive sirolimus and cyclosporine and showed no difference in serum hepci- din concentrations in patient groups (58). This is confounding because sirolimus has been argued to induce PTA. Possible reason for contradictory results in these studies is the difference in immunological risk for transplant recipients and subsequent difference in dose adjustment in each study. Inadequate level of immunogical suppression achieved by sirolimus could result in inadequate $T$ and B-cell suppression and larger than necessary production of IL- 6 in B-cells. This IL- 6 could theoretically induce $H A M P$ transcriprion and hepcidin. Other IS that have been associated with a higher incidence of anemia after renal TX are azathioprine, MPA and MMF $(92,93)$, and their effect on hepcidin concentration should be investigated in future research.

Measurement of hepcidin should be standardized, since immunochemical and MS methods show non comparable hepcidin results (up to 10-fold higher in healthy subjects measured by immunochemical methods) $(25,48,62,66,73,74)$. MS methods show higher precision and specificity to hepcidin-25, but lack of universal internal standard. In order to be able to compare hepcidin results from MS methods a universal internal standard is needed. Calibrators used in MS methods should mimic human serum and urine. Cross reactivity between hepcidin- 25 and hepcidin-20 and -22 should be reduced using more specific antibodies in immunochemical tests. Most researchers agree that measurement of prohepcidin cannot be a substitute for determination of hepcidin because there is no clear relationship or correlation between serum concentrations of prohepcidin and hepcidin $(6,94)$.

Various innovative potential therapeutics, that decrease or increase hepcidin concentration, are currently being tested. Anti-ferroportin antibodies and anticalin PRS-080 are in phase I of clinical trials $(84,85)$, whereas anti-IL-6 receptor antibody (tocilizumab) was shown to improve anemia of inflammation in multicentric Castleman disease $(82,95)$. If these substances prove safe for human use and useful in decreasing plasma hepcidin the next step should be testing them in a multicentric randomized trial on patients with PTA to determine if they are able to reduce ESA-resistance after renal TX. 


\section{Conclusion}

Hepcidin is a central regulatory protein of iron homeostasis and is greatly influenced by immunity. High hepcidin concentrations reflect the status of chronic (in CKD) as well as acute inflammation (in AKI), but the specific mechanisms involved in hepcidin increase are different. CKD is associated with accumulation of hepcidin in serum witch contrib-

\section{References}

1. Krause A, Neitz S, Mägert HJ, Schulz A, Forssmann WG, Schulz-Knappe $P$ et al. LEAP-1, a novel highly disulfide-bonded human peptide, exhibits antimicrobial activity. FEBS Lett 2000;480:147-50. http://dx.doi.org/10.1016/S00145793(00)01920-7.

2. Kulaksiz H, Gehrke SG, Janetzko A, Rost D, Bruckner T, Kallinowski B, Stremmel W. Pro-hepcidin: expression and cell specific localisation in the liver and its regulation in hereditary haemochromatosis, chronic renal insufficiency, and renal anaemia. Gut 2004,53:735-43. http://dx.doi. org/10.1136/gut.2003.022863.

3. Zhang $X$, Rovin BH. Hepcidin expression by human monocytes in response to adhesion and pro-inflammatory cytokines. Biochim Biophys Acta 2010;1800:1262-7. http:// dx.doi.org/10.1016/j.bbagen.2010.08.005.

4. Malyszko J, Levin-laina N, Mysliwiec M, Przybylowski P, Durlik M. Iron metabolism in solid organ transplantation: how far are we from solving the mystery? Pol Arch Med Wewn 2012;122:504-10.

5. Weinstein DA, Roy CN, Fleming MD, Loda MF, Wolfsdorf Jl, Andrews NC. Inappropriate expression of hepcidin is associated with iron refractory anemia: implications for the anemia of chronic disease. Blood 2002;100:3776-81. http:// dx.doi.org/10.1182/blood-2002-04-1260.

6. Young B, Zaritsky J. Hepcidin for Clinitians. Clin J Am Soc Neph 2009;4:1384-7. http://dx.doi.org/10.2215/ CJN.02190309.

7. Peslova G, Petrak J, Kuzelova K, Hrdy I, Halada P, Kuchel $P W$ et al. Hepcidin, the hormone of iron metabolism, is bound specifically to 2-macroglobulin in blood. Blood 2009;113:6225-36. http://dx.doi.org/10.1182/blood-2009-01-201590.

8. Huang ML, Austin CJ, Sari MA, Rahmanto YS, Ponka P, Vyoral $D$ et al. Hepcidin bound to a2-macroglobulin reduces ferroportin-1 expression and enhances its activity at reducing serum iron levels. J Biol Chem 2013;288:25450-65. http://dx.doi.org/10.1074/jbc.M113.471573. utes to anemia and ESA. Hepcidin is the most sensitive marker of iron absorption and the only marker that reflects iron availability. Because of those characteristics it is extensively researched as a therapeutic target, both in anemia and iron overload disease.

\section{Potential confict of interest}

None declared.
9. Nicolas G, Chauvet $C$, Viatte L, Danan JL, Bigard X, Devaux l et al. The gene encoding the iron regulatory peptide hepcidin is regulated by anemia, hypoxia, and inflammation. J Clin Invest 2002;110:1037-44. http://dx.doi.org/10.1172/ JCI0215686.

10. Memoli B, Salerno S, Procino A, Postiglione L, Morelli S, Sirico $M L$ et al. A translational approach to micro-inflammation in end stage renal disease: molecular effects of low levels of interleukin 6. Clinical Science 2010;119:163-74. http:// dx.doi.org/10.1042/CS20090634.

11. Truksa J, Peng H, Lee P, Beutler E. Bone morphogenetic proteins 2, 4, and 9 stimulate murine hepcidin 1 expression independently of HFE, transferrin receptor 2 (Tfr2), and IL-6. Procs Natl Acad Sci USA 2006;103:10289-93. http://dx.doi. org/10.1073/pnas.0603124103.

12. Wrighting DM, Andrews NC. Interleukin-6 induces hepcidin expression through STAT3. Blood 2006;108:3204-9. http:// dx.doi.org/10.1182/blood-2006-06-027631.

13. Core AB, Canali S, Babitt JL. Hemojuvelin and bone morphogenic protein (BMP) signaling in iron homeostasis. Front Pharmacol 2014;5:1-9. http://dx.doi.org/10.3389/fphar.2014.00104.

14. Zhao N, Zhang AS, Enns CA. Iron regulation by hepcidin. J Clin Invest 2013;123:2337-43. http://dx.doi.org/10.1172/ JCl67225.

15. Vecchi C, Montosi G, Zhang K, Lamberti I, Duncan SA, Kaufman $R J$ et al. ER stress controls iron metabolism through induction of hepcidin. Science 2009;325:877-80. http:// dx.doi.org/10.1126/science.1176639.

16. Feder JN, Gnirke A, Thomas W, Tsuchihashi Z, Ruddy DA, Basava $A$ et al. A novel MHC class I-like gene is mutated in patients with hereditary haemochromatosis. Nat Genet 1996;13:399-408. http://dx.doi.org/10.1038/ng0896-399.

17. Muckenthaler M, Roy CN, Custodio AO, Miñana B, de Graaf $J$, Montross $L K$ et al. Regulatory defects in liver and intestine implicate abnormal hepcidin and Cybrd1 expression in mouse hemochromatosis. Nat Genet 2003;34:102-7. http:// dx.doi.org/10.1038/ng1152. 
18. Papanikolaou G, Tzilianos M, Christakis Jl, Bogdanos D, Tsimirika K, MacFarlane J et al. Hepcidin in iron overload disorders. Blood 2005;105:4103-5. http://dx.doi.org/10.1182/blood-2004-12-4844.

19. Roetto A, Papanikolaou G, Politou M, Alberti F, Girelli D, Christakis $J$ et al. Mutant antimicrobial peptide hepcidin is associated with severe juvenile hemochromatosis. Nat Genet 2003;33:21-2. http://dx.doi.org/10.1038/ng1053.

20. Kattamis A, Papassotiriou I, Palaiologou D, Apostolakou $F$, Galani A, Ladis $V$ et al. The effects of erythropoetic activity and iron burden on hepcidin expression in patients with thalassemia major. Haematologica 2006;91:809-12.

21. Peyssonnaux C, Zinkernagel AS, Schuepbach RA, Rankin $E$, Vaulont S, Haase VH et al. Regulation of iron homeostasis by the hypoxia-inducible transcription factors (HIFs). J Clin Invest 2007;117:1926-32. http://dx.doi.org/10.1172/ JCI31370.

22. Valore EV, Ganz T. Posttranslational processing of hepcidin in human hepatocytes is mediated by the prohormone convertase furin. Blood Cell Mol Dis 2008;40:132-8. http:// dx.doi.org/10.1016/j.bcmd.2007.07.009.

23. Liu Q, Davidoff O, Niss K, Haase VH. Hypoxia-inducible factor regulates hepcidin via erythropoietin-induced erythropoiesis. J Clin Invest 2012;122:4635-44. http://dx.doi. org/10.1172/JCl63924.

24. Mastrogiannaki M, Matak P, Mathieu JR, Delga S, Mayeux $P$, Vaulont $S$ et al. Hepatic hypoxia-inducible factor-2 downregulates hepcidin expression in mice through an erythropoietin-mediated increase in erythropoiesis. Haematologica 2012;97:827-34. http://dx.doi.org/10.3324/haematol.2011.056119.

25. Rumjon A, Sarafidis P, Bricant S, Musto R, Malyszko J, Bansal SS et al. Serum hemojuvelin and hepcidin levels in chronic kidney disease. Am J Nephrol 2012;35:295-304. http:// dx.doi.org/10.1159/000336528.

26. Pak M, Lopz MA, Gabayan V, Ganz T, Rivera S. Suppression of hepcidin during anemia requires erythropoietic activity. Blood 2006;108:3730-5. http://dx.doi.org/10.1182/blood-2006-06-028787.

27. Vokurka M, Krijt J, Sulc K, Necas E. Hepcidin mRNA levels in mouse liver respond to inhibition of erythropoiesis. Psys Res 2006;55:667-74.

28. Ashby DR, Gale DP, Busbridge M, Murphy KG, Duncan ND, Cairns $D$ et al. Erythropoietin administration in humans causes a marked and prolonged reduction in circulating hepcidin. Haematologica 2010;95:505-8. http://dx.doi. org/10.3324/haematol.2009.013136.

29. Ashby DR, Gale DP, Busbridge M, Murphy KG, Duncan ND, Cairns $D$ et al. Plasma hepcidin levels are elevated but responsive to erythropoietin therapy in renal disease. Kidney Int 2009;75:976-81. http://dx.doi.org/10.1038/ki.2009.21.

30. Pinto JP, Ribeiro S, Pontes $H$, Thowfeegu S, Tosh D, Carvalho $F$ et al. Erythropoietin mediates hepcidin expression in hepatocytes trough EPOR signaling and regulation of C/EBPa. Blood 2008;111:5727-33. http://dx.doi.org/10.1182/blood-2007-08-106195.
31. Mariani R, Trombini P, Pozzi M, Piperno A. Iron Metabolism in Thalassemia and Sickle Cell Disease. Mediterr J Hematol Infect Dis 2009;1:e2009006. http://dx.doi.org/10.4084/mjhid.2009.006.

32. Lakhal S, Talbot NP, Crosby A, Stoepker C, Townsend AR, Robbins PA et al. Regulation of growth differentiation factor 15 expression by intracellular iron. Blood 2009;113:1555-63. http://dx.doi.org/10.1182/blood-2008-07-170431.

33. Vanrenterghem $Y$, Ponticelli $C$, Morales JM, Abramowicz D, Baboolal $K$, Eklund B et al. Prevalence and management of anemia in renal transplant recipients: a European survey. Am J Transplant 2003;3:835-45. http://dx.doi.org/10.1034/ j.1600-6143.2003.00133.x.

34. Molnar MZ, Mucsi I, Macdougall IC, Marsh JE, Yagoob M, Main J et al. Prevalence and management of anaemia in renal transplant recipients: data from ten European centres. Nephron Clin Pract 2011;117:127-34. http://dx.doi. org/10.1159/000319660.

35. Malyszko J, Oberbauer R, Watschinger B. Anemia and Erythrocytosis in patients after kidney transplantation. Transp Int 2012;25:1013-23. http://dx.doi.org/10.1111/j.14322277.2012.01513.x.

36. Cassis P, Gallon L, Benigni A, Mister M, Pezzotta A, Solini S et al. Erythropoietin, but not the correction of anemia alone, protects from chronic kidney allograft injury. Kidney Int 2012;81:903-18. http://dx.doi.org/10.1038/ki.2011.473.

37. Karthikeyan V, Karpinski J, Nair RC, Knoll G. The burden of chronic kidney disease in renal transplant recipients. Am J Transplant 2004;4:262-9. http://dx.doi.org/10.1046/j.16006143.2003.00315.x

38. Marcén $R$, del Castillo D, Capdevila L, Fernandez-Fresnedo $G$, Rodrigo $E$, Cantarell $C$ et al. Achieving chronic kidney disease treatment targets in renal transplant recipients: results from a cross-sectional study in Spain. Transplantation 2009;87:1340-6. http://dx.doi.org/10.1097/ TP.0b013e3181a23837.

39. Przybylowski P, Malyszko J, Malyszko JS, Koc-Zorawska E, Sadowski J Mysliwiec M. Anemia in heart and kidney allograft recipients: is there a role for hepcidin? Transpl Proc 2010;42:4255-8. http://dx.doi.org/10.1016/j.transproceed.2010.09.034.

40. Jairam A, Das R, Aggarwal PK, Kohli HS, Gupta KL, Sakhuja $V$ et al. Iron status, inflammation and hepcidin in ESRD patients: The confounding role of intravenous iron therapy. Indian J Nephrol 2010;20:125-31. http://dx.doi. org/10.4103/0971-4065.70840.

41. Kaysen GA, Müller HG, Ding J, Chertow GM. Challenging the validity of the EPO index. Am J Kidney Dis 2006;47:166. http://dx.doi.org/10.1053/j.ajkd.2005.09.013.

42. Zhang Y, Thamer M, Stefanik K, Kaufman J, Cotter DJ. Epoetin requirements predict mortality in hemodialysis patients. Am J Kidney Dis 2004;44:866-76. http://dx.doi.org/10.1016/ S0272-6386(04)01086-8.

43. Singh AK, Szczech L, Tang KL, Barnhart H, Sapp S, Wolfson M et al. Correction of Anemia with Epoetin Alfa in Chronic Kidney Disease. N Engl J Med 2006;355:2085-98. http://dx.doi. org/10.1056/NEJMoa065485. 
44. Drüeke TB, Locatelli F, Clyne N, Eckardt KU, Macdougall IC, Tsakiris $D$ et al. Normalization of hemoglobin level in patients with chronic kidney disease and anemia. N Engl J Med 2006;355:2071-84. http://dx.doi.org/10.1056/NEJMoa062276.

45. Kemna EH, Kartikasari AE, van Tits LJ, Pickkers P, Tjalsma $H$, Swinkels DW. Regulation of hepcidin: insights from biochemical analyses on human serum samples. Blood Cells Mol Dis 2008;40:339-46. http://dx.doi.org/10.1016/j. bcmd.2007.10.002.

46. Kato A, Tsuji T, Luo J, Sakao Y, Yasuda H, Hishida A. Association of prohepcidin and hepcidin-25 with erythropoietin response and ferritin in hemodialysis patients. Am J Nephrol 2008;28:115-21. http://dx.doi.org/10.1159/000109968.

47. Malyszko J, Malyszko JS, Pawlak K, Mysliwiec M. Hepcidin, iron status, and renal function in chronic renal failure, kidney transplantation, and hemodialysis. Am J Hematol 2006;81:832-7. http://dx.doi.org/10.1002/ajh.20657.

48. Ganz T, Olbina G, Girelli D, Nemeth E, Westerman M. Immunoassay for human serum hepcidin. Blood 2008;112:42927. http://dx.doi.org/10.1182/blood-2008-02-139915.

49. Swinkels DW, Wetzels JFM. Hepcidin: a new tool in the management of anaemia in patients with chronic kidney disease? Nephrol Dial Transplant 2008;23:2450-3. http://dx.doi. org/10.1093/ndt/gfn267.

50. Taes YE, Wuyts B, Boelaert JR, De Vriese AS, Delanghe JR. Prohepcidin accumulates in renal insufficiency. Clin Chem Lab Med 2004;42:387-9. http://dx.doi.org/10.1515/CCLM.2004.069.

51. Peters HP, Laarakkers CM, Pickkers $P$, Masereeuw R, Boerman OC, Eek $A$ et al. Tubular reabsorption and local production of urine hepcidin-25. BMC Nephrol 2013;14:70. http:// dx.doi.org/10.1186/1471-2369-14-70.

52. Prowle JR, Ostland V, Catzavacca P, Licari E, Ligabo EV, Echeverri JE et al. Greater increase in urinary hepcidin predicts acute kidney injury after cardiopulmonary bypass. Nephrol Dial Transplant 2012;27:595-602. http://dx.doi. org/10.1093/ndt/gfr387.

53. Ho J, Lucy M, Krokhin O, Hayglass K, Pascoe E, Darroch G et al. Mass spectrometry-based proteomic analysis of urine in acute kidney injury following cardiopulmonary bypass: a nested case-control study. Am J Kidney Dis 2009;53:584-95. http://dx.doi.org/10.1053/j.ajkd.2008.10.037.

54. Ho J, Reslerova M, Gali B, Gao A, Bestland J, Rush DN et al. Urinary hepcidin-25 and risk of acute kidney injury following cardiopulmonary bypass. Clin J Am Soc Nephrol 2011;6:2340-6. http://dx.doi.org/10.2215/CJN.01000211.

55. Zhang X, Nagaraja HN, Nadasdy T, Song H, McKinley A, Prosek $J$ et al. A composite urine biomarker reflects interstitial inflammation in lupus nephritis kidney biopsies. Kidney Int 2012;81:401-6. http://dx.doi.org/10.1038/ki.2011.354.

56. Winkelmayer WC, Chandraker A. Posttransplantation Anemia: management and rationale. Clin J Am Soc Nephrol 2008;3:49-55. http://dx.doi.org/10.2215/CJN.03290807.

57. Al-Khoury S, Shah N, Afzali B, Covic A, Taylor J, Goldsmith D. Post-transplantation anaemia in adult and paediatric renal allograft recipients - Guy's Hospital experience. Nephrol Dial Transplant 2006;21:1974-80. http://dx.doi.org/10.1093/ndt/ gfl121.
58. Maiorano A, Stallone G, Schene A, Infante B, Pontrelli P. Sirolimus interferes with iron homeostasis in renal transplant recipients. Transplantation 2006;82:908-12. http://dx.doi. org/10.1097/01.tp.0000235545.49391.1b.

59. Thaunat $O$, Beaumont $C$, Lechaton $S$, Kreis $H$, Morelon $E$. Late introduction of sirolimus induces anemia in renal transplant recipients. Transplantation 2007;83:1283. http:// dx.doi.org/10.1097/01.tp.0000260424.75005.c1.

60. Sofroniadou S, Kassimatis T, Goldsmith D. Anaemia, microcytosis and sirolimus--is iron the missing link? Nephrol Dial Transplant 2010;25:1667-75. http://dx.doi.org/10.1093/ndt/ gfp674.

61. Grebenshtchikov N, Geurts-Moespot AJ, Kroot JJ, den Heijer $M$, Tjalsma $H$, Swinkels DW et al. High-sensitive radioimmunoassay for human serum hepcidin. J Haematol 2009;146:317-25. http://dx.doi.org/10.1111/j.13652141.2009.07758.x.

62. Zaritsky J, Young B, Wang HJ, Westerman M, Olbina G, Nemeth $E$ et al. Hepcidin--a potential novel biomarker for iron status in chronic kidney disease. Clin J Am Soc Nephrol 2009;4:1051-6. http://dx.doi.org/10.2215/CJN.05931108.

63. Peters HP, Laarakkers CM, Swinkels DW, Wetzels JF. Serum hepcidin-25 levels in patients with chronic kidney disease are independent of glomerular filtration rate. Nephrol Dial Transplant 2010;25:848-53. http://dx.doi.org/10.1093/ndt/gfp546.

64. Kulaksiz H, Theilig F, Bachmann S, Gehrke SG, Rost D, Janetzko $A$, Cetin $Y$ et al. The iron-regulatory peptide hormone hepcidin: expression and cellular localization in the mammalian kidney. J Endocrinol 2005;184:361-70. http:// dx.doi.org/10.1677/joe.1.05729.

65. Kemna EH, Tjalsma H, Willems HL, Swinkels DW. Hepcidin: from discovery to differential diagnosis. Haematologica 2008;93:90-7. http://dx.doi.org/10.3324/haematol.11705.

66. Anderson DS, Heeney MM, Roth U, Menzel C, Fleming MD, Steen $H$. A high throughput MALDI-TOF mass spectrometry method for quantification of hepcidin in human urine. Anal Chem 2010;82:1551-5. http://dx.doi.org/10.1021/ ac902479p.

67. Ward DG, Roberts $K$, Stonelake P, Goon P, Zampronio CG, Martin A et al. SELDI-TOF-MS determination of hepcidin in clinical samples using stable isotope labelled hepcidin as an internal standard. Proteome Sci 2008;6:28. http://dx.doi. org/10.1186/1477-5956-6-28.

68. Kemna EH, Tjalsma $H$, Podust VN, Swinkels DW. Mass spectrometry-based hepcidin measurements in serum and urine: analytical aspects and clinical implications. Clin Chem 2007;53:620-8. http://dx.doi.org/10.1373/ clinchem.2006.079186.

69. Murphy AT, Witcher DR, Luan P, Wroblewski VJ. Quantitation of hepcidin from human and mouse serum using liquid chromatography tandem mass spectrometry. Blood 2007;110:1048-54. http://dx.doi.org/10.1182/blood-2006-11-057471.

70. Li H, Rose MJ, Tran L, Zhang J, Miranda LP, James CA et al. Development of a method for the sensitive and quantitative determination of hepcidin in human serum using LC-MS/ MS. J Pharmacol Toxicol Methods 2009;59:171-80. http:// dx.doi.org/10.1016/j.vascn.2009.02.004. 
71. Bansal SS, Abbate V, Bomford A, Halket JM, Macdougall IC, Thein SL et al. Quantitation of hepcidin in serum using ultra-high-pressure liquid chromatography and a linear ion trap mass spectrometer. Rapid Commun Mass Spectrum 2010;24:1251-9. http://dx.doi.org/10.1002/rcm.4512.

72. Wolff F, Deleers M, Melot C, Gulbis B, Cotton F. Hepcidin-25: Measurement by LC-MS/MS in serum and urine, reference ranges and urinary fractional excretion. Clin Chim Acta 2013;423:99-104. http://dx.doi.org/10.1016/j. cca.2013.04.021.

73. Busbridge $M$, Griffiths $C$, Ashby D, Gale D, Jayantha A, Sanwaiya $A$ et al. Development of a novel immunoassay for the iron regulatory peptide hepcidin. Br J Biomed Sci 2009;66:150-7.

74. Costa E, Swinkels DW, Laarakkers CM, Rocha-Pereira P, Rocha $S$, Reis F et al. Hepcidin serum levels and resistance to recombinant human erythropoietin therapy in haemodialysis patients. ActaHaematol 2009;122:226-9. http://dx.doi. org/10.1159/000253590.

75. Weiss G, Theurl I, Eder S, Koppelstaetter C, Kurz K, Sonnweber $T$ et al. Serum hepcidin concentration in chronic haemodialysis patients: associations and effects of dialysis, iron and erythropoietin therapy. Eur J Clin Invest 2009;39:88390. http://dx.doi.org/10.1111/j.1365-2362.2009.02182.x.

76. Kroot JJ, Kemna EH, Bansal SS, Busbridge M, Campostrini N, Girelli $D$ et al. Results of the first international round robin for the quantification of urinary and plasma hepcidin assays: need for standardisation. Haematologica 2009; 94:1748-52. http://dx.doi.org/10.3324/haematol.2009.010322.

77. Ramos E, Ruchala P, Goodnough JB, Kautz L, Preza GC, Nemeth $E$ et al. Minihepcidins prevent iron overload in hepcidin-deficient mouse model of severe hemochromatosis. Blood 2012;120:3829-36. http://dx.doi.org/10.1182/blood-2012-07-440743.

78. Fung E, Nemeth E. Manipulation oft he hepcidin pathway for therapeutic purposes. Haematologica 2013; 98:1667-76. http://dx.doi.org/10.3324/haematol.2013.084624.

79. Yu PB, Hong CC, Sachidanandan C, Babitt JL, Deng DY, Hoyng SA et al. Dorsomorphin inhibits BMP signals required for embryogenesis and iron metabolism. Nat Chem Biol 2008;4:33-41. http://dx.doi.org/10.1038/nchembio.2007.54.

80. Babitt JL, Huang FW, Xia Y, Sidis Y, Andrews NC, Lin HY. Modulation of bone morphogenic protein signaling in vivo regulates systemic iron balance. J Clin Invest 2007;117:19339. $h$ ttp://dx.doi.org/10.1172/JCl31342.

81. Sasu BJ, Cooke KS, Arvedson TL, Plewa C, Ellison AR, Sheng J et al. Antihepcidin antibody treatment modulates iron metabolism and is effective in a mouse model of inflammation-induced anemia. Blood 2010;115:3616-24. http://dx.doi. org/10.1182/blood-2009-09-245977.

82. Song SNJ, Tomosugi N, Kawabata H, Ishikawa T, Nishikawa T, Yoshizaki K. Down-regulation of hepcidin resulting from long-term treatment with an anti-IL-6 receptor antibody (tocilizumab) improves anemia of inflammation in multicentric Castleman disease. Blood 2010;116:3627-34. http:// dx.doi.org/10.1182/blood-2010-03-271791.
83. Schwoebel F, van Eijk LT, Zboralski D, Sell S, Buchner $K$, Maasch $C$ et al. The effects of the anti-hepcidin Spiegelmer NOX-H94 on inflammation-induced anemia in cynomolgus monkeys. Blood 2013;121:2311-5. http://dx.doi. org/10.1182/blood-2012-09-456756.

84. Pieris AG. First-in-human study to evaluate the safety, tolerability, pharmacokinetics and pharmacodynamics of PRS080. Updated 2015. Available at: https://www.clinicaltrials. gov/ct2/show/NCT02340572. Last accessed November 15, 2015.

85. Eli Lilly and Company. A first human study of a ferroportin antibody. Updated 2011. Available at: http://www.clinicaltrials.gov/ct2/show/NCT01330953. Last accessed November 15, 2015.

86. Cooke KS, Hinkle B, Salimi-Mosavi H, Folta I, King C, Rathanaswami $P$ et al. A fully human antihepcidin antibody modulated iron methabolism in both mice and nonhuman primates. Blood 2013;122:3054-61. http://dx.doi.org/10.1182/ blood-2013-06-505792.

87. Elliott J, Mishler D, Agarwal R. Hyporesponsiveness to erythropoietin: causes and management. Adv Chronic Kidney Dis 2009;16:94-100. http://dx.doi.org/10.1053/j. ackd.2008.12.004.

88. Siddique A, Kowdley KW. Review article: the iron overload syndromes. Aliment Pharmacol Ther 2012;35:876-93. http://dx.doi.org/10.1111/j.1365-2036.2012.05051.x.

89. Kapitsinou PP, Liu Q, Unger TL, Pha J, Davidoff O, Keith B et al. Hepatic HIF-2 regulates erythropoietic responses to hypoxia in renal anemia. Blood 2010;116:3039-48. http:// dx.doi.org/10.1182/blood-2010-02-270322.

90. Hentze MW, Muckenthaler MU, Galy B, Camaschella C. Two to tango: regulation of mammalian iron metabolism. Cell 2010;142:24-8. http://dx.doi.org/10.1016/j.cell.2010.06.028.

91. Besson-Fournier C, Latour C, Kautz L, Bertrand J, Ganz T, Roth MP et al. Induction of activin B by inflammatory stimuli up-regulates expression of the iron-regulatory peptide hepcidin through Smad1/5/8 signaling. Blood 2012;120:431-9. http://dx.doi.org/10.1182/blood-2012-02-411470.

92. Nemeth E, Tuttle MS, Powelson J, Vaughn MB, Donovan A, Ward DM et al. Hepcidin regulates iron efflux by binding to ferroportin and inducing its internalization. Science 2004;306:2090. http://dx.doi.org/10.1126/science.1104742.

93. Vanrenterghem Y. Anemia after kidney transplantation. Transplantation 2009;87:1265-7. http://dx.doi. org/10.1097/TP.0b013e3181a170b7.

94. Borrows R, Chusney G, Loucaidou M, James A, Lee J, Tromp $J V$ et al. Mycophenolic acid 12-h trough level monitoring in renal transplantation: association with acute rejection and toxicity. Am J Transplant 2006;6:121-8. http://dx.doi. org/10.1111/j.1600-6143.2005.01151.x.

95. Kemna $E$, Pickkers $P$, Nemeth $E$, van der Hoeven $H$, Swinkels D. Time-course analysis of hepcidin, serum iron, and plasma cytokine levels in humans injected with LPS. Blood 2005;106:1864-6. http://dx.doi.org/10.1182/blood-2005-03-1159. 